\title{
臓器特異的遺伝子発現制御を目的とした組織押圧核酸導入法の開発
}

\author{
向井英史
}

\section{Development of Tissue Pressure-mediated Transfection Method Aimed at Organ-specific Gene Expression Control}

\author{
Hidefumi MUKAI \\ Graduate School of Pharmaceutical Sciences, Kyoto University, 46-29 Yoshida-shimoadachicho, \\ Sakyo-ku, Kyoto 606-8501, Japan
}

(Received June 18, 2010)

\begin{abstract}
A mechanism-based logical approach is a mainstream of current novel drug therapy development in the context of these trends and, therefore, the elucidation of gene function and the molecular level mechanism analysis of diseases at an individual level in mammals are essential in addition to that in cultured cells. In vivo gene transfection techniques are also indispensable for these purposes as well as the evaluation of gene therapy and nucleic acid-based therapy approaches and clinical applications during the process of development of novel drug therapies. Various recombinant virus and synthetic carrier-mediated transfection methods have been reported, however, above all, naked plasmid DNA transfection without virus vectors, synthetic carriers and special physical devices has attracted much attention, because of its advantages including convenience of preparation and handling and lack of toxicity associated with the transfection agents. In this review, I collect the information of these naked plasmid DNA transfection methods involving tissue pressure-mediated transfection from the comprehensive view point including side effects. Additively, the key physiological phenomena affecting transgene expression, especially activation of transcriptional factors, are reviewed. Combined with conventional approach based with biodistribution control, regulation of physiological change in transfected cells will provide spatial- and temporal-controlled transgene expression at various organs, which leads us to elucidate mechanism of diseases and to develop novel drug therapy in near future.
\end{abstract}

Key words — - transgene expression; tissue pressure-mediated transfection; naked plasmid DNA; transcriptional factor

\section{1. はじめに}

DNA マイクロアレイ技術や高分解能質量分析装 置，バイオイメージングを利用した生体分子間相互 作用解析・生体分子機能解析など，生体関連分野に おける解析技術はこの 20 年程の間に急速に進歩 し，また汎用化された。その結果，ヒトゲノム配列 解読に始まり, 疾患状態における遺伝子発現の網羅 的解析やプロテオーム解析が進み, 膨大な量の遺伝 子・分子レベルの情報が既に蓄積しつつある。これ らの知見は, 薬物治療法開発に対し大きな变革をも

京都大学大学院薬学研究科薬品動態制御学分野 (下606 -8501 京都市左京区吉田下阿達町 46-29)

現所属: 理化学研究所分子イメージング科学研究セン ター分子プローブ動態応用研究チーム（T650-0047 神 戸市中央区港島南町 6-7-3)

e-mail: hmukai@riken.jp

本総説は, 平成 21 年度日本薬学会近畿支部奨励賞（医 療系薬学）の受賞を記念して記述したものである.
たらし，今日では，遺伝子治療，核酸医薬品，分子 標的治療を始めとする, 論理的な新規薬物治療法開 発が標準的な戦略として展開されている。こうした 潮流の中で，培養細胞における遺伝子強制発現や発 現抑制といつた遺伝子発現制御を目的とした遺伝 子，オリゴ核酸導入は汎用される基盤技術となって おり，市販の多彩な導入試薬が疾患機構の解明や治 療標的分子の同定等に利用されている. 近年では, さらに, 疾患状態における生体内の多様な細胞間相 互作用の重要性が認識されており, 非遺伝的な手法 によるトランスジェニック実験動物や疾患モデル動 物の構築などに基づく生体レベルでの遺伝子機能解 析や疾患機構の検討，遺伝子治療及び核酸医薬品の 治療戦略の評価や，研究成果の遺伝子治療・核酸医 薬品への結実に向けて, in vivoにおける遺伝子発 現制御を目的とした核酸導入技術の整備は急務とな っている。しかし，多くの標的臟器において汎用的 
に利用可能な核酸導入法はいまだ確立されておら ず，新しい方法論の開発は最も重要な研究課題の 1 つである.

In vivo 核酸導入法としては，従来，ウイルスの 持つ自然の感染力を利用した方法1)や，in vitro 用 の導入試薬を発展させたカチオン性リポソームやカ チオン性ポリマーなどの合成キャリアを利用した方 法2)が主流である。一方で，導入剂に依存した毒性 の懸念がなく，調製や取り扱いの容易さの点で優れ た，ウイルスベクターや合成キャリア，また特殊な デバイスを用いない，プラスミド DNA 水溶液の注 入に基づくいくつかの方法論が提案されている．本 稿では，これら in vivoでの核酸導入における独自 の方法論の発展について記述し，加えて筆者らが検 討を進めている組織押圧核酸導入法について紹介す る。また，適切な in vitro 実験系がないことから従 来困難であった，それらの外来遺伝子発現機構に関 する議論もなされるようになってきた。こうした知 見は，今後のin vivo における遺伝子導入法の改良 や発展に対し重要な示唆を与えるものと考えられ， 併せて概説する。

\section{2. プラスミド DNA 水溶液の注入による外来遺} 伝子発現の利点と問題点

当初，生体において外来遺伝子を発現させるに は，特殊な細胞内移入機構や核移行機構が必要と考 えられ，リコンビナントウイルスを利用した遺伝子 導入を中心に研究が進められたが，1990 年，マウ スの筋組織に対してプラスミド DNA 水溶液を注入 する，最も単純で簡便な戦略により外来遺伝子の発

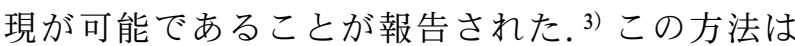
Vascular endothelial growth factor や Erythropoietin などの分泌性タンパク質をコードした遺伝子導入に 基づいた遺伝子治療戦略に応用され，一部臨床試験 も行われている. 4,5$)$ また同様に，肝臓や腫瘍など多 くの組織においてプラスミド DNA 溶液の直接注入 により外来遺伝子発現が得られることが確かめられ ている. ${ }^{6,7)}$ しかし，組織へのプラスミド DNA 溶液 の直接導入では遺伝子発現が注入部位局所に限局さ れてしまう。分泌性の一部のタンパク質を除き多く のタンパク質は産生された細胞内で機能するため, 通常，遺伝子治療や非遺伝性のトランスジェニック 動物作製においては，標的組織におけるより広範な 細胞への遺伝子導入が要求され，経血管投与に基づ
く方法に利がある，通常のプラスミド DNA 溶液の 静脈内投与による標的臓器での外来遺伝子発現は困 難であるが，マウスに対して大容量のプラスミド DNA 水溶液を急速に尾静脈内へ注入するハイドロ ダイナミクス法により肝臓において高効率な遺伝子 発現が得られることが，1999 年 Liu らと Wolff ら

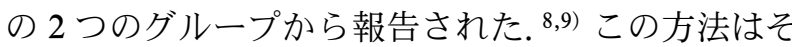
の簡便性と遺伝子発現の高さが最大の特徴であり, 遺伝子治療戦略の検証や，プラスミド DNA ベク ターの有効性評価などにおいて汎用されており，加 えて， small-interfering RNA（siRNA）導入による 遺伝子発現抑制へも応用されている. ${ }^{10)}$ しかし適用 が肝臓での遺伝子発現制御に限局され，しかも肝組 織障害が引き起こされる点が問題である. ${ }^{11)}$

\section{3. 組織押圧核酸導入法による臓器特異的遺伝子 発現制御}

筆者らは，上記のような簡便性と高効率性に加 え, 組織障害性の低い核酸導入法の開発を目的に組 織押圧核酸導入法と呼んでいる方法論について検討 を進めている. ${ }^{12,13)}$ 本手法は，プラスミド DNA を 静脈内投与した後，標的組織（腎臓，あるいは，肝 臓，脾臓）に対し制御された弱い押圧を加える単純 で簡便な方法であり，Liu らが先駆的な論文で報告 したマウスに対しプラスミド DNA 溶液を尾静脈内 注入後，腹部を圧迫すると顕著な肝障害なく肝臓に おいて導入遺伝子の発現が得られる現象を発展させ たものである. ${ }^{11)}$

組織に対する押圧は，印加する圧力の定量並びに 制御を目的に自作した Fig. 1 に示す圧力制御デバ イスを用いている。バネの伸縮を利用して組織に印 加する圧力を制御可能なシステムである。このデバ イスを利用した種々の押圧条件の検討から，驚くべ きことに，遺伝子発現レベルは 1 秒間， 1 回，0.59 $\mathrm{N} / \mathrm{cm}^{2}$ という極めて短時間かつ温和な条件で飽和 し，その発現は臓器特異的かつ高効率なことが明ら

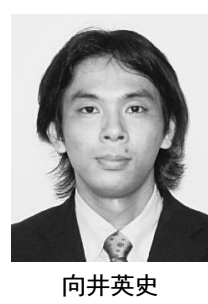

理化学研究所分子イメージング科学研 究センター分子プローブ動態応用研究 チーム研究員. 2009 年 3 月京都大学大 学院薬学研究科博士後期課程修了, 博 士 (薬学) 取得. 京都大学博士研究員 を経て，2009 年 10 月より現職。現在 の研究テーマは，核酸プローブによる 分子イメージング及びドラッグデリバ リーシステム開発。 
a

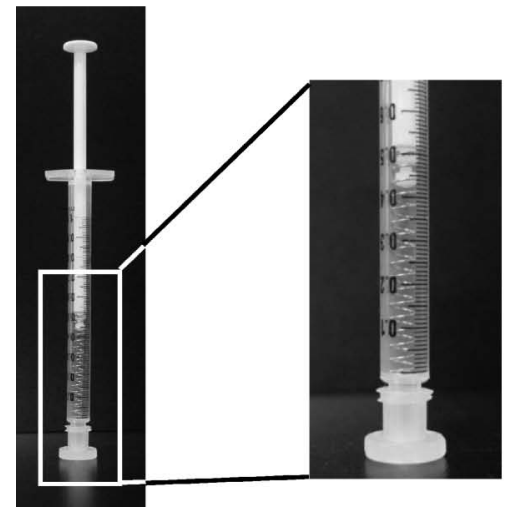

b

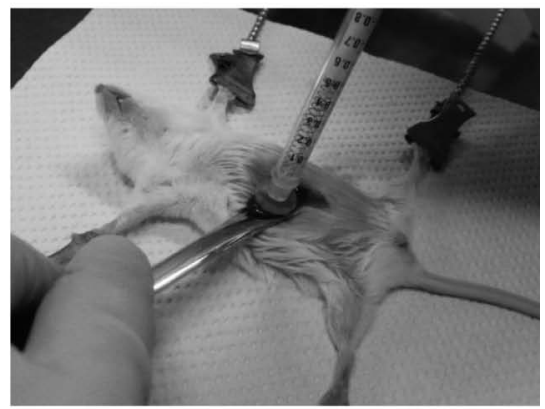

Fig. 1. Method of Controlling and Quantifying the Degree of Pressure

(a) The pressure control device and (b) directions for use of this device. The pressure control device was made by setting the spring in the barrel of the syringe and attaching a polypropylene cap with an area of $1 \mathrm{~cm}^{2}$ at the tip of the syringe. When using this device, we held the tissue between the cap of the device and a spatula and then pushed the plunger against the spatula (b). The pressure value was estimated from the measured displacement of the spring and its force constant. Also, the device was calibrated, using an electronic balance, before experimentation. (Reprinted from Ref. 13).

a

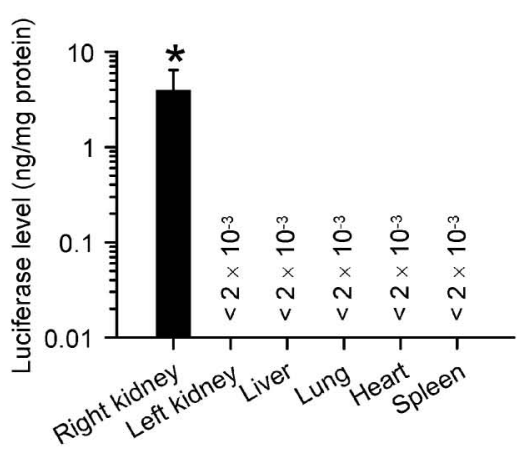

d

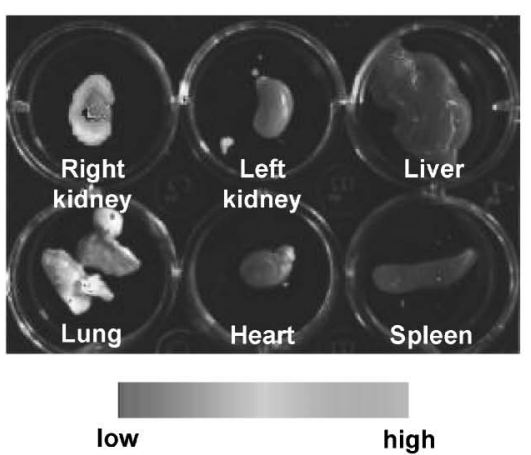

b

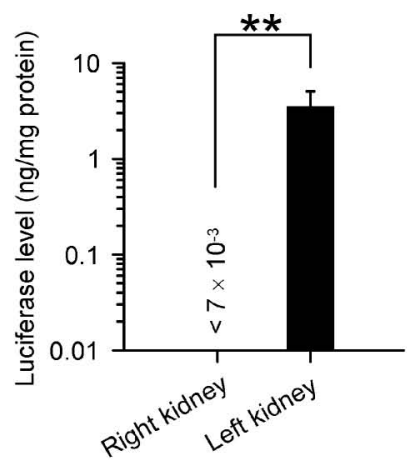

e

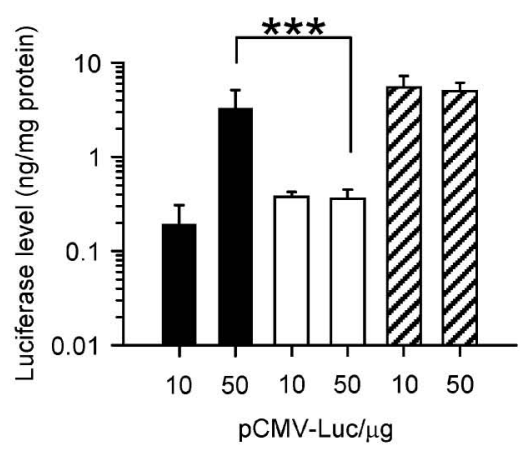

C

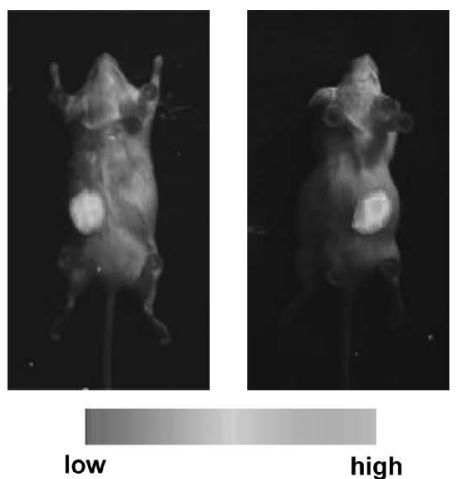

$\mathbf{f}$

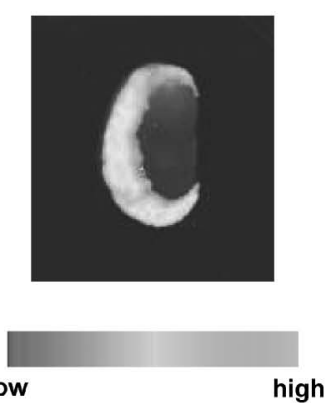

Fig. 2. Kidney-specific Plasmid DNA Transfection by Renal Pressure-mediated Transfection Method

Luciferase levels of various organs (a, b) and in vivo imaging (c) $12 \mathrm{~h}$ after $100 \mu \mathrm{g}$ pCMV-Luc administration to the right (a, c right) or left (b, cleft) kidney. ${ }^{*} p<0.01 v s$. the other organs. ${ }^{* *} p<0.01$. Each value represents the mean + S.D. $(n=4$ or 5$)$. (d) Imaging of the isolated organs $12 \mathrm{~h}$ after $100 \mu \mathrm{g} \mathrm{pCMV-Luc} \mathrm{ad-}$ ministration to the right kidney. (e) Luciferase levels obtained by the renal press-mediated transfection method (black) were compared with renal parenchymal injection (white) and electroporation (hatched). ${ }^{* * *} p<0.01$. Each value represents the mean + S.D. ( $n=4$ or 5 ). (f) Imaging of the pressed right kidney $12 \mathrm{~h}$ after $100 \mu \mathrm{g}$ pCMV-Luc administration to the right kidney. (Reprinted from Ref. 12 with permission of Elsevier).

かとなつた. ${ }^{13)}$ 腎臓について例示すると [Figs. $2(\mathrm{a})-$ (d)], レポーター遺伝子としてルシフェラーゼ遺 伝子発現プラスミド DNA（pCMV-Luc）100 $\mu \mathrm{g}$ を
投与した 12 時間後の遺伝子発現は押圧した腎臓特 異的であり，そのレベル (約 $4 \mathrm{ng} / \mathrm{mg}$ protein $)^{12)}$ は，代表的な静脈内投与に基づく遺伝子導入である 
リコンビナントアデノウイルス静脈内投与後の肝 臓，脾臓における遺伝子発現 $(1-30 \mathrm{ng} / \mathrm{mg} \text { protein })^{14)}$ や，リポプレックスやポリプレックス投与による肺 での遺伝子発現 $(0.2-3.5 \mathrm{ng} / \mathrm{mg} \text { protein })^{15-17)}$ に匹 敵し，腎実質への直接注入を用いたエレクトロポ レーション法 $(5 \mathrm{ng} / \mathrm{mg} \text { protein })^{12)}$ と比較しても同 程度と高効率である $[\mathrm{Fig} .2(\mathrm{e})]$ 。加えて，プラス ミド DNA が経血管的に投与されるため，皮質，髄 質外帯領域の広範囲から遺伝子発現が得られる

[Fig. 2(f)]. 12)

また，DNA ワクチンやサイトカイン遺伝子治療 における重要な標的の 1 つと考えられる脾臟や，多 様な遺伝子疾患の原因臟器であり分泌性タンパク質 産生機関としても重要な肝臓においても，同様に， 組織押圧導入法に基づく臟器特異的かつ高効率な外 来遺伝子発現が可能であり, ${ }^{13)}$ 加えて, ルシフェ ラーゼを標的とした siRNA を pCMV-Luc と同時投 与すると， siRNA 投与量依存的な遺伝子発現抑制 がみられ，本方法はこれらの臟器における遺伝子発 現抑制に対しても適用可能なことが示唆されてい る. ${ }^{12,13)}$ さらに，腎組織押圧核酸導入法の場合を例 にとると，腎機能の指標である血中尿素窒素並びに クレアチニン值は非処置群と比較して変化せず，顕 著な腎組織障害はみられない（エレクトロポレーシ ヨン法では，一過性に両值とも増加する).12)この ように組織押圧核酸導入法により，顕著な組織障害 を引き起こすことなく, 臟器特異的に高効率かつ, 広範囲への核酸導入による遺伝子発現制御が可能で ある。

なお，炎症性サイトカイン産生は，導入遺伝子発 現や治療効果に影響を及ぼす，in vivo での核酸導 入における重要な副作用として認識されており，併 せて的確な情報収集が求められている。特に,

Kleinman らにより，最近，血管内皮細胞増殖因子 (vascular endothelial growth factor; VEGF)-A や, その受容体 VEGFR1 を標的とした SiRNAにおける 血管新生抑制作用が非特異的なインターフェロン応 答によるという重要な報告がなされた. ${ }^{18)}$ さらに, 抗インフルエンザ siRNA における抗ウイルス作用

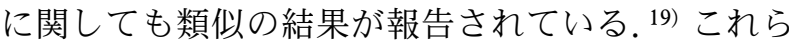
の情報は，炎症性サイトカイン産生が的確な疾患の 機構解明及び，遺伝子治療や核酸医薬品開発におけ る戦略の評価を擋乱する要素であることを示唆して
いる，筆者らは，組織押圧核酸導入法に関し，顕著 な炎症性サイトカイン産生の惹起がないことも明ら かとしており, ${ }^{13)}$ 生物医学研究における汎用的な実 験技術としても利があると期待される.

\section{4. 組織押圧核酸導入法に基づく外来遺伝子発現 の支配機構}

In vivo 遺伝子導入に基づく外来遺伝子発現にお いては，克服を要する多くの生体内障壁が存在す る。体内動態，細胞内移行，核移行，転写・翻訳等 が，その遺伝子発現効率に影響を及ぼす重要な素過 程であり，各遺伝子導入法ではこれらの段階を制御 することによって遺伝子発現が達成されていると考 えられる，通常，非ウイルス性の遺伝子導入法で投 与するプラスミド DNA は高分子ポリアニオンであ り, 細胞膜との静電反発から細胞との相互作用が低 $<,{ }^{20)}$ また，静脈内投与後 Scavenger 受容体を介し た機構により速やかに肝臓の細網内皮系に取り込ま れるため, ${ }^{21)}$ 標的組織並びに，細胞への移行性の向 上は遺伝子導入法開発において重要な要素であるこ とから，動態制御の観点に基づく戦略が主流であつ た。しかし，培養細胞におけるリコンビナントアデ ノウイルスと代表的な in vitro 用導入試薬である LipofectAMINE に基づく外来遺伝子発現におい て，転写が両者の遺伝子発現レベルの差を決定付け る過程であるとの報告のように, ${ }^{22)}$ 遺伝子導入され た細胞内での生理現象にも焦点が向けられ始めてい る。特に，組織押圧核酸導入のような，in vivo 遺 伝子導入における独自の方法論に基づいた外来遺伝 子発現に対して支配的な生理現象の解明は興味深い.

組織押圧核酸導入法に基づく投与後のプラスミド DNA の体内分布について，放射標識体を用いて評 価すると，標的組織においてわずかに有意な分布の 増加がみられるものの，速やかに肝臓に集積するな ど，全身レベルでは，通常の静脈内投与と比較して 大きな差がない. ${ }^{23)}$ 一方で，蛍光標識体を用いた組 織レベルでの観察では標的組織において顕著な分布 の増加がみられ，投与量全体からするとわずかでは あるが，組織への押圧によって標的組織の細胞内へ 移行したプラスミド DNA が遺伝子発現に関与して いると考えられる. ${ }^{23)}$ また，プラスミド DNA の細 胞内移行の向上は一過性であり，その期間は，腎臟 において 10 秒程度，肝臓の場合でも数分以内と短 く, 23) ハイドロダイナミクス法において移行性が向 
上していると推察される期間（15-30 分程度 $)^{24)}$ と 比較すると，極めて短い．Liu らは，腹部の圧迫に よる血圧の上昇が肝臟における遺伝子発現と相関 し，ハイドロダイナミクス法と類似の生理現象であ る可能性を示唆しているが, ${ }^{25)}$ 組織押圧導入法にお いて組織障害が誘発されないこととプラスミド DNA の細胞内移行向上が短時間であることとの関 連が推察される。ハイドロダイナミクス法において もプラスミド DNA 溶液の注入速度を制御するシス テムの構築が行われているように, ${ }^{26)}$ 効率的でかつ 組織障害性の低い，圧力に基づいた遺伝子導入法に は，制御された，適度な期間のプラスミド DNA 標 的組織細胞内移行性の向上が求められる.

また，より重要な知見として，組織押圧導入法に 基づく外来遺伝子発現に関し，特定の転写因子の関 与を示すデータも得られている. Figure 3 に示すよ うに, 様々な転写因子結合部位をエンハンサー領域 として有するルシフェラーゼ発現プラスミド DNA を用い評価すると， activator protein-1（AP-1）や nuclear factor $\kappa \mathrm{B}(\mathrm{NF}-\kappa \mathrm{B})$ への結合部位を有する
プラスミド DNA において，高い遺伝子発現がみら れた [Figs. 3 (a) and (b)]. ${ }^{23)}$ 加えて，投与後初期 に AP-1 の構成タンパクの遺伝子 $c$-fos, $c$-jun に関 し mRNA 量の増加が認められた [Figs. 3 (c) and (d) ]. ${ }^{23)} c$-fos や c-jun の遺伝子発現と AP-1 依存性 遺伝子の発現にタイムラグがあること（inducible NO synthase の場合 6-12 時間) 27,28) を合わせて考察 すると，遺伝子発現レベルの経時的な減弱との間に 相関がみられ [Figs. 3(c) $-(\mathrm{e})]$ ，組織押圧導入法に より転写因子の一過性の活性化が引き起こされて, 高効率な遺伝子発現に関与している可能性が推察さ れる。本現象は外来遺伝子高発現への転写因子活性 化の寄与が最近報告されたハイドロダイナミクス法 における結果 ${ }^{29)}$ と酷似しており，導入細胞に対し類 似の生理的変化を及ぼしている可能性を推察させ る.プラスミド DNA 細胞内移行後の転写過程に関 しては，一度低下した外来遺伝子発現が，ヒストン 脱アセチル化酵素の投与 ${ }^{30)}$ や物理刺激の再印加29,31) によって再活性化される現象が報告されたことによ り，遺伝子発現に影響を及ぼす重要な過程として認 a

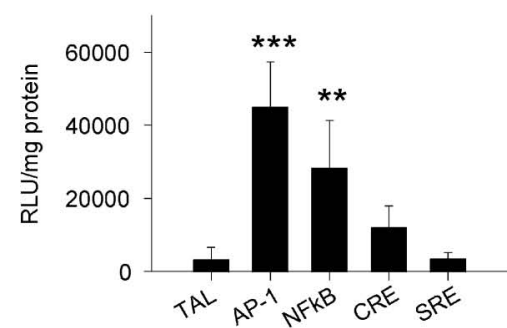

b

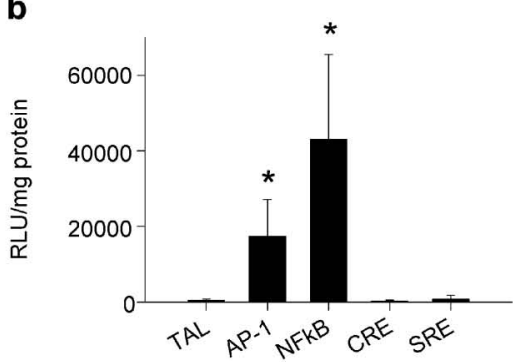

C

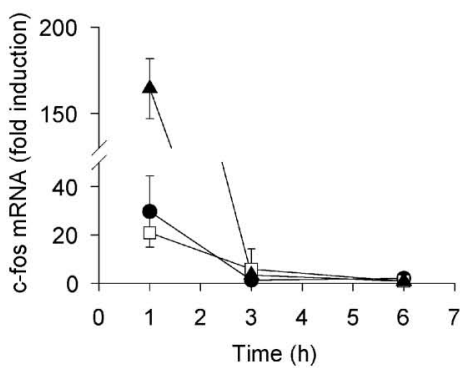

d

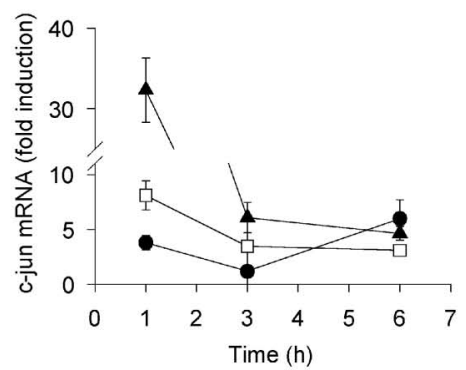

e

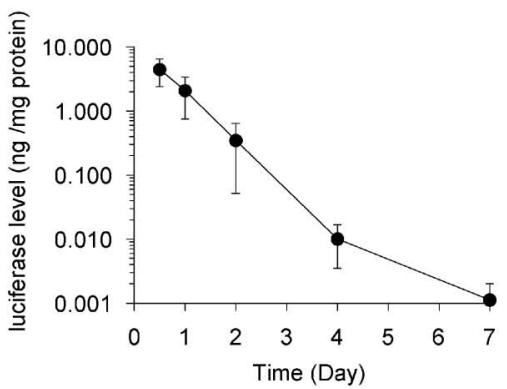

Fig. 3. Effect of the Transcription Factors on Transgene Expression Level of the Tissue Pressure-mediated Transfection

Luciferase levels of the right kidney (a) and left lobe of the liver (b) $12 \mathrm{~h}$ after administration of $100 \mu \mathrm{g}$ pTAL-Luc, pAP-1-Luc, pNF $\kappa \mathrm{B}-\mathrm{Luc}$, pCRE-Luc, and pSRE-Luc by renal (a) and hepatic (b) tissue pressure-mediated transfection. Each value represents the mean +S.D. ( $n=3$ or 4). Key: TAL, pTAL-Luc; AP-1, pAP-1-Luc; NF $\kappa$ B, pNF $\kappa$ B-Luc; CRE, pCRE-Luc; and SRE, pSRE-Luc administration groups. ${ }^{*} p<0.05,{ }^{*} p<0.01,{ }^{* * *} p<0.001 v s$. pTAL-Luc injection group. $c$-fos (c) and c-jun (d) mRNA levels after $100 \mu \mathrm{g} \mathrm{pCMV-Luc} \mathrm{administration} \mathrm{by} \mathrm{renal} \mathrm{(closed} \mathrm{circles)} \mathrm{and} \mathrm{hepatic} \mathrm{(open} \mathrm{squares)} \mathrm{tissue} \mathrm{pressure-mediated} \mathrm{transfec-}$ tion and $5 \mu \mathrm{g}$ pCMV-Luc administration by the hydrodynamics-based transfection (closed triangles). The level was normalized using the mRNA level of gapdh in each sample. Then, the $x$-fold induction was calculated using the mRNA levels in untreated mice and those receiving the administration. Each value represents the mean \pm S.D. $(n=3)$. (e) Time-course of luciferase gene expression after administration of $100 \mu \mathrm{g}$ pCMV-Luc by renal pressure-mediated transfection. Each value represents the mean \pm S.D. ( $n=4$ or 5). (Reprinted from Ref. 23 with permission of the Pharmaceutical Society of Japan). 
識が高まりつつある。これらの知見は，遺伝子発現 の高効率化並びに，持続化にとって，転写因子の活 性化が制御されるべき重要な要素であることを示し ている．様々な内在性遺伝子の発現制御を担ってい るため注意が必要であるが，AP-1 や NF- $\kappa \mathrm{B}$ の適 度な活性化の促進が，今後の生体における外来遺伝 子発現手法の開発において重要な戦略となると考え られる。

最後に, 今後詳細な議論が必要だが，組織押圧導 入法やハイドロダイナミクス法による遺伝子導入後 の細胞内での生理現象に類似していると想像させる 細胞レベルの現象として，周期的伸張刺激（cyclic stretch）に基づく外来遺伝子発現増強について記し ておきたい. ${ }^{32}$ 培養細胞に対し，市販の導入試薬あ るいは，エレクトロポレーションによる遺伝子導入 の後, 周期的伸張刺激を印加すると遺伝子発現が増 強される。細胞骨格の再構成 ${ }^{33)}$ や転写因子 AP-1 や $\mathrm{NF}-\kappa \mathrm{B}$ の関与 ${ }^{34)}$ が示唆されており，この in vitroに おける導入細胞に対する圧力と遺伝子発現の関連 は，本稿で述べた in vivo 独自の遺伝子導入法との 接点となる可能性があり, 今後の研究の進展が期待 される。

\section{5. おわりに}

筆者らが検討を進めている組織押圧核酸導入法を 含む，プラスミド DNA 水溶液の注入による外来遺 伝子発現は，その簡便性，臟器特異性，高効率性な ど多くの利点から，in vivo 核酸導入技術の整備に 対して有用な手法の 1 つになると考えられる。 た，今後，外来遺伝子発現の高効率化並びに持続化 を指向し，従来の体内動態制御的な戦略に加え，本 稿で概説した導入細胞内での生理現象までを考慮す ることによって，多様な臟器において，時空間的に 制御された遺伝子発現が可能になり，疾患機構の解 明及び，新規薬物治療法開発につながるものと期待 している.

謝辞 本研究は, 京都大学大学院薬学研究科薬 品動態制御学分野において, 橋田 充教授, 山下富 義准教授，川上 茂講師の諸先生の御指導の下実施 されたものであり，賜りました愍篤なる御指導，御 鞭撻に対し，深甚なる謝意を表します。また，種々 の貴重な御助言を頂き，実験の一部に御協力頂きま した教室員の皆様に深謝します。実験の一部に共同
研究として参画頂き，御助言，御指導を賜りました 京都大学大学院工学研究科小寺秀俊教授, 寺尾京平 博士に心から感謝の意を表します。

\section{REFERENCES}

1) Kay M. A., Glorioso J. C., Naldini L., Nat. Med., 7, 33-40 (2001).

2) Brown M. D., Schatzlein A. G., Uchegbu I. F., Int. J. Pharm., 229, 1-21 (2001).

3) Wolff J. A., Malone R. W., Williams P., Chong W., Acsadi G., Jani A., Felgner P. L., Science, 247, 1465-1468 (1990).

4) Isner J. M., Baumgartner I., Rauh G., Schainfeld R., Blair R., Manor O., Razvi S., Symes J. F., J. Vasc. Surg., 28, 964-973 (1998).

5) Tripathy S. K., Svensson E. C., Black H. B., Goldwasser E., Margalith M., Hobart P. M., Leiden J. M., Proc. Natl. Acad. Sci. USA, 93, 10876-10880 (1996).

6) Hickman M. A., Malone R. W., LehmannBruinsma K., Sih T. R., Knoell D., Szoka F. C., Walzem R., Carlson D. M., Powell J. S., Hum. Gene Ther., 5, 1477-1483 (1994).

7) Stopeck A. T., Hersh E. M., Akporiaye E. T., Harris D. T., Grogan T., Unger E., Warneke J., Schluter S. F., Stahl S., J. Clin. Oncol., 15, 341-349 (1997).

8) Liu F., Song Y. K., Liu D., Gene Ther., 6, 1258-1266 (1999).

9) Zhang G. F., Budker V., Wolff J. A., Hum. Gene Ther., 10, 1735-1737 (1999).

10) McCaffrey A. P., Meuse L., Pham T. T. T., Conklin D. S., Hannon G. J., Kay M. A., Nature, 418, 38-39 (2002).

11) Liu F., Huang L., Hepatology, 35, 1314-1319 (2002).

12) Mukai H., Kawakami S., Hashida M., Biochem. Biophys. Res. Commun., 372, 383-387 (2008).

13) Mukai H., Kawakami S., Kamiya Y., Ma F., Takahashi H., Satake K., Terao K., Kotera H., Yamashita F., Hashida M., Hum. Gene Ther., 20, 1157-1167 (2009) .

14) Sakurai H., Sakurai F., Kawabata K., Sasaki T., Koizumi N., Huang H., Tashiro K., Kurachi S., Nakagawa S., Mizuguchi H., J. Control. Release, 117, 430-437 (2007).

15) Dow S. W., Elmslie R. E., Fradkin L. G., Lig- 
gitt D. H., Heath T. D., Willson A. P., Potter T. A., Hum. Gene Ther., 10, 2961-2972 (1999).

16) Zou S. M., Erbacher P., Remy J. S., Behr J. P., J. Gene Med., 2, 128-134 (2000) .

17) Goula D., Benoist C., Mantero S., Merlo G., Levi G., Demeneix B. A., Gene Ther., 5, 1291-1295 (1998).

18) Kleinman M. E., Yamada K., Takeda A., Chandrasekaran V., Nozaki M., Baffi J. Z., Albuquerque R. J. C., Yamasaki S., Itaya M., Pan Y. Z., Appukuttan B., Gibbs D., Yang Z. L., Kariko K., Ambati B. K., Wilgus T. A., DiPietro L. A., Zhang K., Smith J. R., Taylor E. W., Ambati J., Nature, 452, 591-597 (2008) .

19) Robbins M., Judge A., Ambegia E., Choi C., Yaworski E., Palmer L., McClintock K., MacLachlan I., Hum. Gene Ther., 19, 991999 (2008).

20) Mahato R. I., Takakura Y., Hashida M., Crit. Rev. Ther. Drug Carr. Syst., 14, 133-172 (1997).

21) Kawabata K., Takakura Y., Hashida M., Pharm. Res., 12, 825-830 (1995).

22) Hama S., Akita H., Ito R., Mizuguchi H., Hayakawa T., Harashima H., Mol. Ther., 13, 786-794 (2006) .

23) Mukai H., Kawakami S., Takahashi H., Satake K., Yamashita F., Hashida M., Biol. Pharm. Bull., 33, 1627-1632 (2010).
24) Kobayashi N., Nishikawa M., Hirata K., Takakura Y., J. Gene Med., 6, 584-592 (2004)

25) Liu F., Lei J., Vollmer R., Huang L., Mol. Ther., 9, 452-457 (2004).

26) Suda T., Suda K., Liu D. X., Mol. Ther., 16, 1098-1104 (2008).

27) Okada S., Obata S., Hatano M., Tokuhisa T., Int. Immunol., 15, 2275-1282 (2003).

28) Menegazzi M., CarcereriDePrati A., Suzuki H., Shinozuka H., Pibiri M., Piga R., Columbano A., LeddaColumbano G. M., Hepatology, 25, 585-592 (1997).

29) Nishikawa M., Nakayama A., Takahashi Y., Fukuhara Y., Takakura Y., Hum. Gene. Ther., 19, 1009-1020 (2008).

30) Fujii N., Isaka Y., Takabatake Y., Mizui M., Suzuki C., Takahara S., Ito T., Imai E., Nephrol. Dial. Transplant., 21, 2745-2753 (2006).

31) Ochiai H., Fujimuro M., Yokosawa H., Harashima H., Kamiya H., Gene Ther., 14, 11521159 (2007).

32) Taylor W., Gokay K. E., Capaccio C., Davis E., Glucksberg M., Dean D. A., Mol. Ther., 7, 542-549 (2003).

33) Geiger R. C., Taylor W., Glucksberg M., Dean D. A., Gene Ther., 7, 725-731 (2006).

34) Lam A. P., Dean D. A., J. Gene Med., 10, 668-678 (2008). 